\title{
MONOLINGUAL AND BILINGUAL PRACTICES: REVERSING POWER RELATIONS DURING A FESTIVITY IN PONDALA
}

\section{Laura Siragusa}

\begin{abstract}
This paper aims to demonstrate how people can shift prevailing power relations when engaging in distinct bilingual practices, especially in convivial settings in a remote, yet familiar to the speakers, rural environment. My paper is based on extensive fieldwork conducted among Veps, a Finno-Ugric population, traditionally living in rural settlements in north-western Russia. Most elderly Vepsian villagers are bilingual and can speak Vepsian, their heritage language, as well as Russian. In their daily bilingual practices, they tend to conform to the overarching language ecology and to employ Vepsian and/or Russian, depending on the dominant forces (including language ideologies) present at the time of speech. This often means speaking Russian in the presence of Russian-only speakers and in more institutional settings. Such practices tend to match ideologies and language behaviours which already emerged during the Tsarist era and Soviet times. However, by introducing a vignette situated in Pondala, a Vepsian village in Vologda Oblast, I show how Veps can reverse uneven relations of power once the ordinary social dynamics are shaken. This paper founds its argumentation on three key concepts: language ecology, and power and agency in the heritage language.
\end{abstract}

Keywords: agency, bilingual and monolingual practices, convivial settings, language ecology and power, Vepsian heritage language

\section{INTRODUCTION: VEPSIAN HERITAGE LANGUAGE AND}

\section{LANGUAGE ECOLOGY}

The day started a little differently from the ones I had already spent in Pondala, a Vepsian village of 36 permanent residents, mostly over 60 years old, in the Babaevo district of Vologda Oblast (see Figs. 1 \& 2). By the time I woke up, Nadezhda Pavlovna, the director of the local Dom Kultury (Rus. 'House of Culture'), with whom I was staying, had already warmed up the wooden stove, fed the dogs and chickens and made a few trips back and forth to the House of Culture. ${ }^{1}$ We were going to celebrate Den Pozhilykh Liudei (Rus. 'Day of the Elderly') on that day, October 1, 2013. And Nadezhda Pavlovna was responsible 
for the cultural activities. I found her standing next to the window rehearsing the sequence of the planned activities. She asked me where she could find the CDs for the music since they had gone missing from the House of Culture. She later found out that a neighbour had taken and burned them on to his faulty computer; thus, he had damaged the quality of the sound. There would be no music during the festivity! "What kind of prazdnik (Rus. 'holiday, festivity') is it if people cannot dance?" she asked out loud as if to herself. ${ }^{2}$ She then swore in Russian in her rage for which she later apologised. Using bad language was very unusual for Nadezhda Pavlovna since she had demonstrated to generally avoid engaging in conflictual verbal behaviours. The other villagers also stressed how important it was to use a positive vocabulary, not to upset and/or offend anyone verbally. But that was an exceptional day, I soon discovered - a convivial day when people were allowed to turn the more usual order of things upside down, also in regard to verbal practices.

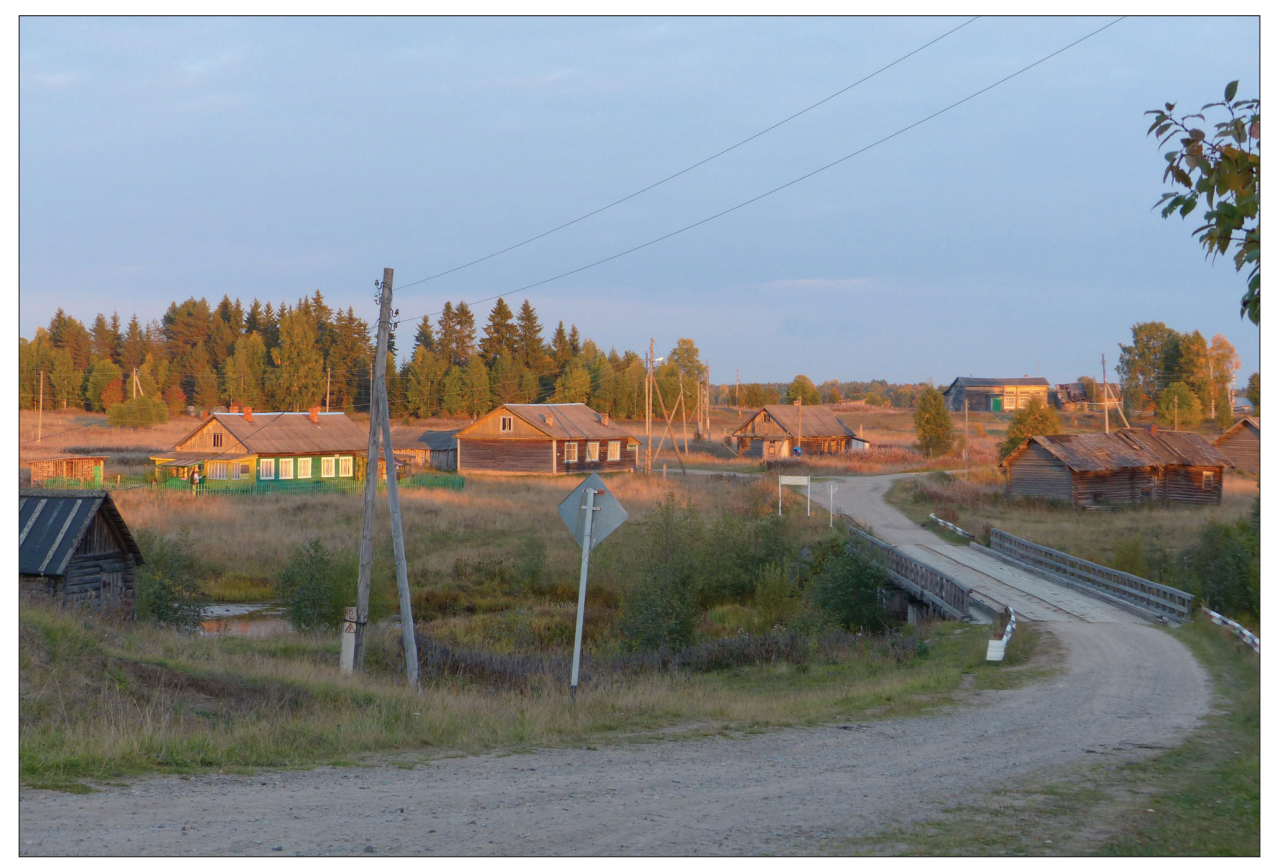

Figure 1. Pondala, a Vepsian village in the Babaevo District of Vologda Oblast, Russia. Photograph by Laura Siragusa 2013. 
Just like Nadezhda Pavlovna, the other villagers in Pondala are bilingual as they master their heritage language, Vepsian, as well as Russian. Heritage language can be translated as ičemoi kel' in Vepsian, which literally means own language. I have deliberately chosen not to translate this Vepsian phrase as 'mother tongue' or 'native language' and, instead, to adopt the phrase heritage language in English. Indeed, my choice hints at a political discourse on heritage, which cannot be dismissed when dealing with a minority language, such as Vepsian (Strogalshchikova 2008). Vepsian is traditionally spoken among Veps in rural settlements of the Republic of Karelia, Leningrad and Vologda Oblasts in north-western Russia (Grünthal 2011; Puura et al. 2013). The Vepsian language comprises three distinct dialects (northern, central, and southern) (Zaiceva 1995). The northern-speaking Veps, also referred to as Veps of Lake Onega, live either in Petrozavodsk or in villages along the south-western shores of Lake Onega, in the Republic of Karelia (see Fig. 2). Central Vepsian speakers are based in both Leningrad and Vologda Oblasts. Their dialect can be divided into central-eastern and western Vepsian, such as the one spoken in Pondala. Southern Vepsian is spoken in the Boksitogorsk province of Leningrad Oblast. The Vepsian language has a long-standing oral tradition and only in the 1920s-30s during korenizatsiya (Rus. 'indigenisation'), a group of scholars from Leningrad Oblast created a standard form and introduced it in the education system (Kettunen \& Siro 1935; Salminen 2009; Setälä et al. 1951; Strogalshchikova 2008). In 1937, however, Vepsian was abruptly forbidden in the public domain and only in the late 1980s a group of activists from the Republic of Karelia took on the duty to revitalise it by creating a new standard form and promoting it for publishing and educational purposes (Puura et al. 2013; Strogalshchikova 2008). Such activities provided several results: one of those was positioning Vepsian politically. In 2000, Vepsian obtained the status of national language (alongside Karelian), while Russian remained the official state language, according to the Languages in the Republic of Karelia Act (Strogalshchikova 2004). In the same year, Veps gained the status of minority indigenous peoples of the Russian Federation, which also granted them the status of minority indigenous peoples of the North, Siberia and the Far East in 2006 (Strogalshchikova 2008: 23).

Beside this reason, ongoing debates on the meaning of heritage have pushed me towards choosing the phrase heritage language when translating ičemoi kel'. In this paper, Vepsian heritage language refers to communicative and experiential practices that find their origin in the past, and also to those practices that are constructed today in the engagement with the present language ecology; hence, it focuses on its dynamicity. This choice matches the study made by Kirshenblatt-Gimblett (1998) and Smith and Akagawa (2009), who appreciate 
heritage not as something 'lost and found, stolen and reclaimed', but rather as 'something new in the present which has recourse to the past' (KirshenblattGimblett 1998: 149). This way the phrase heritage language encompasses both the oral communicative practices prevalent among Vepsian elderly villagers, and the new domains of Vepsian mostly used among the urban Vepsian youth (those in their late twenties / early thirties). Even though I will not focus on the latter aspect of language use, it is worth mentioning that the Vepsian youth employs Vepsian standard form often for written purposes, especially in Petrozavodsk; hence, they contribute to the creation of new domains.

Last, my choice to employ the phrase heritage language closely links to the Russian phrase rodnoy yazyk (lit. own, native language) also used among bilingual Veps in reference to Vepsian, where rodnoy has its root in the word rod (Rus. 'family, kin, clan'). Rod is also found in such words as rodstvennik (Rus. 'relative, kinsman'), narod (Rus. 'people, nation, folk'), priroda (Rus. 'nature') (Paxson 2005: 59). And in this sense the use of the phrase heritage language adequately summarises the perception that many Veps (especially elderly villagers) displayed towards their mother tongue, i.e., as a way to relate and reach out to the surrounding rural environment, its human and non-human beings.

This paper explores bilingual practices in the Vepsian heritage language and Russian with reference to uneven relations of power. Maintaining that Veps engage in specific bilingual communicative practices in accordance with the dominant forces in which they find themselves (e.g. language ecology), I show how they also demonstrate agency and retain power by overturning the more ordinary status quo during convivial events, such as the Day of the Elderly in Pondala. Such festivities instigate untypical language practices where people may reveal attitudes of dissent and reversion of power hierarchy through their bilingual skills. When employing the phrase language ecology, I refer to contemporary ideas of interaction and socialisation with the world through oral (but also written) practices (Garner 2004; Mühlhäusler 1996; 2000). I put 'written' in brackets on purpose since this practice is not at the centre of my present discussion and, henceforth, I will not pursue it. More specifically, Garner (2004: 36) defines it as a 'holistic, dynamic, interactive, situated' phenomenon. This implies that people speak in accordance or discordance with the dominant forces (including language ideologies) present in one place at a specific time. In other words, the speakers negotiate their relations, sometimes manifesting to retain more agency and gaining social power through their speech acts. And I borrow the definition of agency from Ahearn (2001: 112), in which 'agency refers to the socio-culturally mediated capacity to act', particularly focusing on bilingual behaviours as strategies of inclusion and exclusion, and inversion of socially accepted power relations. Veps have demonstrated to try and avoid conflict in 
their speech acts also in order to maintain the fragile socio-political balance in which they find themselves; yet, they might drop such speech strategies when ordinary life is subverted, as is the case of the festivity in Pondala. The paper is structured in such a manner: stemming from a historical summary of VepsoRussian relations, I will focus on the power and agency of bilingual practices with reference to language ideologies developed in cities and villages. Thus, I will present the festivity in Pondala, linked to a discourse around power and agency in language.

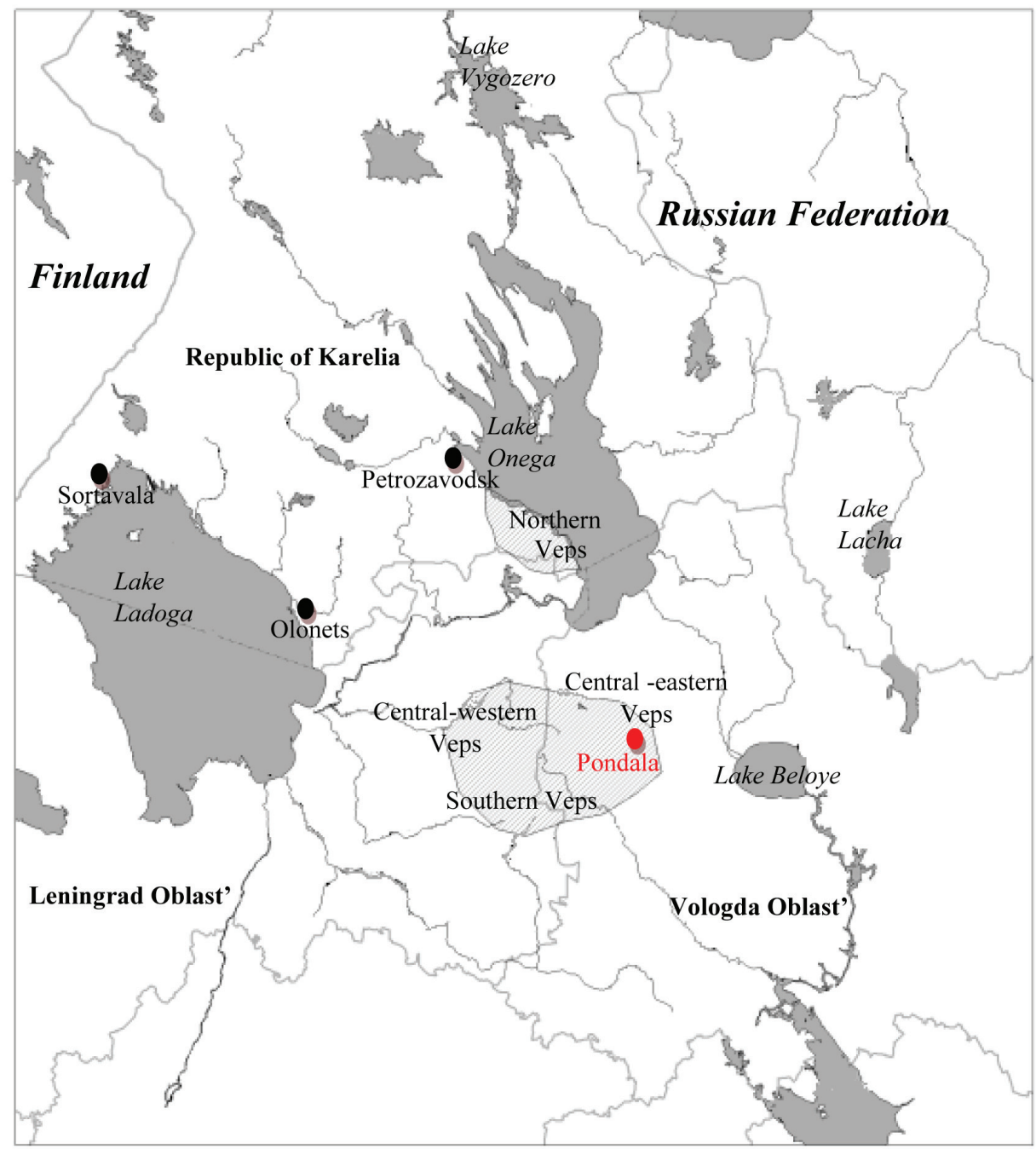

Figure 2. Map of the territory with Vepsian settlements (striped sections), adapted from Mullonen (2012). Pondala is indicated in the centre of the map. 


\section{VEPSO-RUSSIAN RELATIONS IN HISTORY}

In order to better appreciate how power relations between Veps and Russians are intertwined with contemporary social practices, including language use, I will provide a brief historical synopsis for this north-western Russian territory. When making reference to Russians, I do not aim to reinforce ideas of ethnic or bounded groups, as per the Soviet model, which went as far as believing that such boundedness could be observed, studied, and enclosed in categories, often based on biological assumptions (King 2011; Slezkine 1994). Mixed marriage and movement within the USSR contributed to breaking down some of these constructed boundaries; so, when making reference to Russians, I am alluding to those who claim Russian nationality and whose heritage language is Russian, and also to those who represent political power and with whom Vepsian activists and villagers have difficult relations. The latter often live in urban settings and cover administrative and political roles. In this section I aim to contextualise uneven relations of power, given the rise of specific ideologies already in the past, and to show how those are strictly convoluted in contemporary everyday social practices. Despite recognising the violence of some historical events and how these might have affected Veps, in this paper I also allow and do not disregard agency on behalf of the speakers when negotiating their speech acts; hence, I do not hint at these historical events as a cause-and-effect and one-way vector linearity, but more as a display of complex relations which existed in the past and still continue in the present.

According to the available historical documentation, Veps have never retained political power in this north-western territory of Russia. On the contrary, they have been split under more than one political administration since the Tsarist time, despite living in a rather compact territory. This territory used to be even more compact. Indeed, in the fourteenth century the area covered by Vepsian settlements enclosed a larger territory, reaching Lake Beloye in the south, Lake Ladoga in the west, Lake Vygozero in the north, and Lake Lacha in the east (Mullonen 2012) (see Fig. 2). After several conflicts between Sweden and Russia in the sixteenth century, the Vepsian traditional territory began to demean (Kolesov et al. 2007). In 1617, with the peace of Stolbovo, the Swedes obtained the land comprising the Karelian Isthmus and northern Ladoga, where in 1632 they founded the city of Sortavala (ibid.) (see Fig. 2). In response, Russians built a fortress on the eastern shore of Lake Ladoga and founded the city of Olonets (see Fig. 2). The Vepsian population was then split into two administrations: part of Veps went under the Novgorod administration, part under Olonets.

In the eighteenth and nineteenth centuries many migrants reached this north-western territory, since timber, iron, and mining industries had devel- 
oped here. Such a huge and sudden movement of people caused a lack of land, which forced many to migrate elsewhere (Strogalshchikova 2008). Among those, two Vepsian colonies left north-western Russia and reached the guberniya of Irkutsk in 1911-1913, and a third colony arrived there in 1927-1928, supported by the migration policy that was in place at the time (Strogalshchikova 2008). It appears that throughout the period of Tsarist rule, the political authorities chose not to take an active role in fulfilling the Vepsian needs. Immediately after the October Revolution, the Soviet authorities took a provisional change of direction in the policies for indigenous peoples. However, the actual motivations behind such decisions appeared to be driven primarily by centralising ideologies. Indeed, as soon as the Soviets came to power, they re-organised the territory, dividing it into a hierarchy of regions (Kurs 2001; Smith 1999). Nonetheless, a unified Vepsian land was never established and Veps remained administratively split (Kurs 2001: 72). Yet, the census carried out in 1926 showed a growth in the number of those who claimed Vepsian nationality (32,773 in total compared to 25,400 in 1897$)$, the majority of whom $(24,186)$ lived in Leningrad Oblast (Strogalshchikova 2008). At the time 8,587 Veps lived in the Karelian territory. Such an increase in the number of Veps was possibly due to the positive effects of korenizatsiya and the attempts to promote Vepsian standard form also in the education system.

However, this favourable period soon came to an end. The political programme to promote the national cultures and languages was not sustainable and did not always match the general objectives of the Soviet Union. So, the mid-30s witnessed a sudden change in policies. The immediate result of this was seen in the educational measures taken by the regional authorities. While Vepsian was the language of instruction in the Vepsian villages of Leningrad Oblast until 1936, Finnish was adopted in the Karelian Autonomous Soviet Socialist Republic (KASSR). However, Vepsian became the language of instruction for Veps in the KASSR in 1937, while it was abolished in the Vepsian villages of Leningrad Oblast, where Veps had been deprived of their national status and were not included in the list of nationalities in the 1939 census (Kurs 2001: 73). These continuous political changes had an impact on the population, and also on their language use, as many elderly villagers still recollect.

The initial Soviet project aimed to overcome backwardness and elevate the non-Russians to a higher cultural level by providing literacy to all the nationalities. Indeed, such derogatory attitudes towards indigenous languages and cultures found their roots in previous missionaries' activities. The Five-Year Plan and the Soviet prescriptions for development (Anderson 1991: 13) did not succeed and their legacy is still visible in the attitude that many Russians and non-Russians bear towards the minority languages and cultures. It comes as 
no surprise that using Russian words instead of Vepsian synonyms became more prestigious among the villagers; some dropped Vepsian once and for all, especially in those villages closer to urban centres where ideologies of progress and civilisation were more strongly felt (author's field notes 2010, 2013). ${ }^{3}$

The introduction of the Five-Year Plan not only left Veps in a state of underdevelopment compared to Russians, but it also changed entirely the structure of the villages, the lifestyle of the villagers, their habits and traditions. Stalin introduced into the village life the kolkhozy, or co-operative farm organisations, and the sovkhozy, or state farms, which all peasants had to join. Those who tried to oppose the collectivisation were mostly identified as kulaks, or rich land-owners, and were either deported or killed (Shearer 2006; author's field notes 2010, 2013). The animals that Veps highly regarded as a food provision and part of their sebr (Veps 'community') also began to fade away. Besides the social transformations that took place within the villages, changes also began to occur in the composition of the population in urban as well as rural settings. Movements from the village to the city started taking place more and more regularly after the October Revolution (Leasure \& Lewis 1967). Between 1926 and 1937, official figures show that the urban population of the Soviet Union doubled, from about 26 to 52 million (Shearer 2006: 200). In Karelia, the urban population rose by 325,000 (Conquest 1986). The growth in the population of Karelia was also due to the construction of the railroad, which was built from St. Petersburg to Murmansk through Karelia (Laine 2001). This enabled many loggers to move north for work, especially from Belorussia and Ukraine (Yegorov 2006). Besides the northwards movement within the USSR, immigration also consisted of some 25,000 Finns moving into the Soviet Union from Canada, the United States and Finland between the 1920s and 1930s (Gelb 1993). Karelia had become a multi-ethnic republic with a population composed of indigenous groups (such as Veps, Karelians and Russians) and immigrants (such as Finns, Ukrainians, Byelorussians and Tatars) (Kostiainen 1996). This clearly facilitated communication in Russian, especially in the city, where more people came together.

In the mid-1930s, Stalin began to mistrust certain ethnic groups as he suspected they could have loyalties outside of the Soviet Union (Shearer 2006: 211). Among those groups were Germans, Poles, Finns, and the Asian groups of the Far East (Shearer 2006). Consequently, Finns and other ethnic groups closely associated with them became the primary target of Stalin's repressions and of the great mass purges of 1937-1938, including Veps (ibid.: 212). By the end of the 1930s, Veps had lost their status as an ethnic minority in Leningrad Oblast (Klementyev et al. 2007: 13). The census carried out in 1939, right after Stalin's mass purges, presented the following situation: the Vepsian popula- 
tion had dropped from 24,186 in 1926 to 15,571 in Leningrad Oblast, while the number had risen from 8,587 to 9,388 in Karelia. However, it should be noted that the Vepsian rural population had dropped both in Karelia and Leningrad Oblast, that is from 8,474 to 6,504 and from 24,045 to 14,424 , respectively (Strogalshchikova 2008).

Vepsian village life was further revolutionised by the human losses during the Winter War and World War II, and by the huge migration that took place at the end of the conflict. At least 400,000 people, among whom were Karelians, Veps and Finns, moved to Finland (Mead 1952: 52). Between 1939 and 1959, the Vepsian population dropped by about a quarter (Strogalshchikova 2008). The land had been ravaged and devastated. Many men had either left or died. For many years, women outnumbered men in the Vepsian villages and this also disrupted the traditional village lifestyle. This phenomenon was, in fact, typical across the USSR. Moreover, the assimilation policies that followed Stalin's death continued to compromise life in the villages. The policy promoted by Khrushchev between the late 1950s and mid-1960s represented one of the main agents that determined Vepsian movement from the villages to (mainly) the cities. At the Twenty-Second Party Congress in 1961, Khrushchev expressed the need to redistribute manpower (Grandstaff 1980: 21). The policy of liquidation of the villages without prospects was then launched (Yegorov 2006). This policy classified the villages into two categories, those with prospects and those without prospects. The latter stopped being provided with any investment in public services and infrastructure (Kurs 2001: 73). Since its promotion, this policy affected the traditional lifestyle of Veps (and other village dwellers in Russia) irreversibly (Strogalshchikova 2008). It caused migration mainly to urban areas and made the remaining villages larger and further apart from each other. Indeed, during my fieldwork, some villagers also explained how they moved with their families to larger villages, in which the Vepsian dialect was different, and how they were ridiculed for this (author's field notes 2010, 2013). Given such language ecology and language ideologies, some then decided to drop speaking Vepsian, embracing mainly Russian. The concept of language ideologies follows the paradigm by Woolard and Schieffelin (1994) and Schieffelin et al. (1998), i.e., they comprise belief systems shared by members of a group and these extend to language. Besides, the number of mixed marriages grew and this compelled many to stop speaking their heritage language in favour either of Russian or of the heritage language of their spouse (Kaiser 1994). This was particularly the case in the cities where ideas of civilisation also contributed to the language choice made by the speaker, since Vepsian was still considered backward as opposed to Russian. Indeed, these verbal practices reflect the overarching language ecology, comprising ideologies, where languages are classified 
in line with specific social hierarchies. Such a situation also hints at identity issues as some of the Soviet citizens began identifying themselves as Russians, despite their Vepsian (or other) origin (author's field notes 2010, 2013).

As previously mentioned, in this section I did not focus on the cause-effect relationship between the present-day situation and these historical and often violent events. Instead, by presenting this historical synopsis I aim to show how relations between Veps and Russians have often been tense and difficult. These convoluted relations continue today and they are often intertwined with the ideologies and language behaviours that feed such an uneven playing field. Veps, or those who claim Vepsian nationality, very carefully employ their heritage language in the presence of non-speakers of Vepsian. And it could be argued that this reflects carefulness and protection from unequal power relations that years of violent (although, sometimes a more subtle violence) policies have reinforced. ${ }^{4}$ But it also alludes to a Vepsian localised rural epistemology, according to which demonstrating respect towards the environment, its human and non-human inhabitants, guarantees protection and safety for the villagers. It is no surprise that the reversion of such widespread hierarchies and power relations occurs in places where Veps feel safer, in the more remote villages those surrounded by the woods.

\section{Living in the woods}

Before elaborating on the social symbolism and practices convoluted in the phrase living in the woods, it is important to clarify the concept of power in relation to language. Indeed, in this paper its conceptualisation is at least twofold, depending on the language ideologies I am referring to, and the overarching language ecology. In the section above, power is construed as a political instrument used by a few to gain control over others, reinforcing inequality and altering - sometimes irreversibly - people's everyday life and, consequently, their communicative practices (Blommaert 2010; Philips 1999). In other words, language decline is perceived as an indicator of social inequalities, while language maintenance enacts the efforts to reverse those inequalities, by giving power to the underprivileged. In this section, power gains a different colouring, which Guss (1986) and Cruikshank (2005) also make reference to in their work. These scholars claim that the oral form of the language carries power for some indigenous groups. That is, the groups described by Guss and Cruikshank appreciate that verbal practices might influence the course of life events and exercise power in the spoken word when engaging with the world. 
These two descriptions of power in language use can overlap, as appears to be the case of the Vepsian ways of speaking. Indeed, my work with Veps led me to interpret their careful verbal practices as a way to prevent complications and conflicts, and to guarantee social agreement both when engaging with Russian speakers and when dwelling in the woods. Overall, they appreciate that spoken language has the power to influence life events for better or for worse, so it needs to be used carefully. Veps are often depicted as ostorozhnye lyudi (Rus. 'careful people'), and they also tend to describe themselves this way. And this description appears to encompass also their bilingual practices. Demonstrating carefulness conveys avoiding verbal conflict and maintaining an equal condition for everyone, in which nobody stands out against the other beings. Once these conditions are guaranteed, Veps are ready to be open and share experiences of unity and social cohesion. If these conditions are not met, however, they might shut any channel of exchange and communication, and sometimes use verbal practices against those who, voluntarily or not, caused harm.

Besides being depicted as careful people, Veps are also described as those living in the woods, a connotation to which I want to draw particular attention with reference to verbal practices. The phrase living in the woods represents a double-edged sword, since for the urbanites this often means being far from civilisation and modernity, but it also means safety and being well-fed for many villagers. It appears that early-Soviet ideas of modernity still permeate some of the ways that the city dwellers comprehend life and its evolutionary stages. Instead, the elderly villagers tend not to view the woods as indicating a lack of civilisation. They tend to understand the forest as a place rich in produce (such as berries and mushrooms), a protection from external forces, where the Vepsian language serves to avoid conflicts and to maintain relations with the other, human and non-human, inhabitants of this territory (author's field notes 2010, 2013).

The city-dwellers of this north-western territory of Russia often appraise places as civilised or not civilised, which echoes the Soviet discourse on evolution and backwardness. Civilisation can comprise a number of domains and metaphors, most often linked to the family khozyaystvo (Rus. 'housekeeping and farming'). For example, people who live in brick flats or houses are considered more civilised than those living in wooden flats or houses. Electric cookers and stoves are regarded as more civilised appliances than those functioning with gas. Houses or flats with a bathroom and a toilet connected to the sewage system are also deemed as civilised. All such civilised appliances and technologies are often missing in the villages, in the woods, while they are available in urban areas. Living in the woods has become synonymous with away from civilisation and loaded with negative connotations among this north-western multi-ethnic 
population. Paxson (2005: 128) also acknowledges how for Russians the woods often represent a place of both 'munificence and malevolence', due to the abundance of fruits and general products, but also as they may disorientate those entering. In any case, both qualities are wild for Russians.

Urban dwellers have adopted a complex attitude towards those living in the villages. On the one hand, they look at them as not civilised enough and put them in a lower rank in social hierarchy. On the other hand, they perceive the relational power that the villagers have established with this rural environment and often demonstrate fear of it. Entering a foreign land means putting oneself at risk. The forest, for example, is a place of danger and venturing into it can cause trouble and even lead to death, as one is exposed to foreign forces (Paxson 2005; author's field notes 2010). The Russian fear of the other and suspicion of what is foreign forces Veps to speak Russian in the presence of Russian speakers. Indeed, Veps often claim to adopt Russian in the presence of only-Russian-speaking interlocutors. This is also visible in public places such as the shops and post office in the villages. They often justify their language choice as a matter of good manners and politeness; but, in fact, this is also a means of avoiding conflicts and securing safety. By speaking Russian, Veps reassure Russian-only speakers that nothing bad is being said about them. In other words, the person to whom they speak dictates their language choice. Politeness is not the only reason for taking on such a bilingual strategy as people are continually in the process of building their practices (language practices, too). And they can demonstrate agency in multiple ways, even when apparently submissive, since for some protecting themselves and their co-villagers is more important than preserving or imposing their heritage language.

Besides, embracing Russian ways of speaking may mirror those practices when Russian was forced on to people. The majority of elderly Vepsian villagers use Russian words when describing their work and school years, such as kolkhozy (Rus. 'collective farms'), prepodavat' (Rus. 'to teach'), predmet (Rus. 'subject'), urok (Rus. 'class') and ekzamen (Rus. 'examination'). They also tend to provide numbers in Russian. These words come from memories of the time when Vepsian was prohibited and Russian words were adopted to cover most domains of life outside the domestic environment. Referencing back to these days, therefore, triggers the use of Russian. Similarly, memories that depict conversations with Russian-monolingual individuals also prompt the use of Russian. As it were, Veps appear to continuously negotiate their speech acts with the dominant ecology, constituted by human and non-human beings, memories, ideologies, and urban as well as rural settings.

The more remotely from urban influence the village is located, the more one is likely to hear mainly Vepsian heritage language. This is primarily the case 
with the villages I visited in Vologda and Leningrad Oblasts. Veps often believe that a respectful relation with the forest can guarantee them safety, and this is often reflected in their ways of speaking. Monolingual Vepsian practices help Veps maintain a dialogue with the animals and the spirits dwelling in this territory, also because such a dialogue may prevent the occurrence of conflicts and difficulties. Indeed, the relations with the animals display both closeness and care. On the one hand, elderly villagers perceive the animals as part of their sebr (Veps 'community'). Hence, they believe that the animals can speak their heritage language. Kaži miaugub (Veps 'the cat mews'), kägi kukkub (Veps 'the cuckoo cuckoos'), lambaz bäläidab (Veps 'the sheep bleats'), kana kotkotab (Veps 'the chicken clucks') are some examples of the use of onomatopoeia in Vepsian when reproducing the sounds made by animals. If the animals come from outside the külä, then the villagers exhibit the need to speak Russian to them. ${ }^{5}$ Irina Yuryevna owns several goats in Pondala and she once explained how she had to speak Russian to them since they were not born in the village. She clarified, "Or else they would not understand." On the other hand, the villagers watch carefully the behaviour of the animals as this might convey important messages which are not necessarily auspicious. The messages not only concern seasonal instances, but also future predictions. For example, Veps traditionally believe that when the hawk cries, the rain will come or that when the cuckoo calls, the barley will not grow (Vinokurova 2006: 70, 90). It will grow when the cuckoo stops calling (ibid.: 90). It is also said that when the raven caws, somebody will die, and the same goes for the night owl (ibid.: 76, 84). Some of these interactions still perpetuate today, and the villagers displayed concern when the messages were interpreted as unwelcome and bothersome (author's field notes 2010, 2013).

Monolingual practices also allow Veps to engage with the hengid (Veps 'spirits') that inhabit the külä, although some villagers might not reveal their belief in them right away (author's field notes 2010, 2013). This was not the case in Pondala and in other Vepsian villages in Leningrad Oblast, where the elderly villagers closely monitored my language behaviour, and often suggested that I use language carefully and positively so as not to upset the spirits. Indeed, I was often advised to refrain from swearing in the kül'bet' (Veps 'sauna'), to always thank the forest spirits upon departure, not to say that I would be quick in some activities as the speed and outcome of my actions did not depend on me, but on the host of the environment in which I found myself. Some of those spirits are mecaižand (spirit of the forest), vedenižand (spirit of the water), pertinižand (spirit of the house and land where the house is built), kül'betižand (spirit of the kül'bet', sauna) where the Vepsian word ižand means the head of the house, the host. Some Vepsian villagers, called tedai (literally, 'the one who 
knows the way') or noid (Veps 'sorcerer') have learned from their predecessors of the ways to negotiate with the spirits. They can perform Vepsian zagovory (Rus. 'charms, enchantments') in order to reach a compromise with the spirits and find lost cattle in the forests and swamps, decide where to build a house, how to settle disputes, etc. (author's field notes 2013; Vinokurova 2006). ${ }^{6}$

Vepsian elderly villagers also claim to experience unity between the environment and themselves when employing their heritage language, and more specifically their dialect of origin. This enables them to react more spontaneously to life events and to feel closer to their emotions. As some claimed, they could 'better express what they were feeling', when speaking their dialect. This unity is also expressed in the coming together of speech acts and physical engagement. Communicative practices happen via spoken language as well as physical engagement (Bateson 1972; Hanks 1996; Ingold 2004), when dwelling in the forest, fishing, attending funerals, or visiting the deceased in the cemetery (author's field notes 2010, 2013). In this sense, speaking the heritage language can function as a tool to attune to the environment and oneself. Yet, Veps are aware of the power embedded in their heritage language and know that the desired social agreement might crumble as soon as language is misused.

Indeed, monolingual Vepsian practices may not always open channels of communication, foster unity, and guarantee safety. In a few cases Veps warned me that they could turn their back to me and become vengeful in case I harmed them in one way or another. The villagers in Leningrad Oblast told me stories of how the local noid could engage in verbal enchantments in order to damage others (AKNTs; author's field notes 2013). So, they suggested that I should be careful. When trust is not gained, these monolingual practices have the power to influence life events against those who caused harm. However, while the noid may engage in such verbal practices behind the curtains and not show him/ herself out in the open, I witnessed how certain communication channels could be closed during festivities taking place in Pondala. The festive atmosphere, aggravated by abundant alcohol use, and protection from the woods, enabled Veps to bring to light some of the tensions they generally repress in favour of social agreement and safety.

\section{REVERSING POWER RELATIONS IN CONVIVIAL SETTINGS IN PONDALA}

I will now return to the initial vignette and describe the event that took place on the Day of the Elderly in Pondala, with reference to power relations and bilingual verbal practices. Pondala is an example of a remote village, only partly 
influenced by the rhetoric and practices widespread in the city. It is $25 \mathrm{~km}$ from the closest village (Kuya) and $60 \mathrm{~km}$ from the local administrative centre (Timoshino). The roads leading to Kuya and Timoshino are mostly surrounded by forests and swamps and the road is only partly paved, making it difficult to reach the village. Besides, public transport to Babaevo (i.e. the closest and biggest urban centre) runs only once a week - if it does! There is no mobile phone connection and only a few villagers have a landline. Some public phone boxes are scattered around the village, but they only function with a phone card that can be bought at the post office and is not always available. Vepsian activists and city dwellers often claim that the partial isolation has enabled Veps to maintain communication in their heritage language and safeguarded them from external, and possibly unfavourable, forces.

By midday a total of 15 people, mostly women, had gathered at the House of Culture from different parts of the village. Indeed, the overarching külü, Pondala, is divided into six sub-districts, separated by the River Ivoda and the forest. These are Kindaevo, Nikonovo Gora, Bereg, Sloboda, Aksyonovo and Turzhino. This year three visitors also attended the event. One of them was Ekaterina Ivanovna, a former resident of Pondala, who had moved to Narva, Estonia, during her youth. Ekaterina Ivanovna makes regular visits to her niece in Pondala. She understands Vepsian, and the longer she stays in the village, the more fluently she speaks it. Then there was Anastasia Yuryevna, a Russian friend of Maria Alekseyevna, who is a local Vepsian villager. Anastasia Yuryevna lives in Babaevo and often visits her friend in Pondala in the summer. This implies that all the other villagers not only have seen her before, but also know details of her private and personal life. Despite her frequent visits to Pondala, she does not speak Vepsian. Lastly, there was me - a researcher interested in Vepsian matters. During my stay in Pondala I engaged with almost every villager and spoke Vepsian as much as I could, employing Russian when I was particularly tired.

The festivities lasted all day long. Nadezhda Pavlovna had organised some activities to start the celebrations. As soon as we arrived, the attendees read some poems, performed some games, sang chastushki ${ }^{7}$, and awarded prizes that the local administration had granted. At this point and not surprisingly, all the guests performed in Russian, since it is the language associated with political and administrative matters. Then we all sat around the table and the initial formal tone of the event was abandoned. I sat at the right end of the table, next to a group of Vepsian village women (which I will not identify individually since they share a common social function for the purpose of this paper). I was also sitting opposite to Anastasia Yuryevna and Maria Alekseyevna. At the beginning of the event Anastasia Yuryevna and Maria Alekseyevna spoke Russian, 
whereas the other women spoke Vepsian to one another. As the atmosphere became more convivial and alcohol was being consumed in large quantities, language dynamics and interaction changed rather drastically.

At first, drinking facilitated opening the channels of communication, but it also later hastened the closure. During the event, Anastasia Yuryevna consistently praised her friend Maria Alekseyevna for her cooking skills, often addressing her as "the best cook and nicest person in the village" (Fig. 3). In the beginning Maria Alekseyevna accepted the compliments silently, waving at her friend and indicating her to stop. When these compliments became persistent, Maria Alekseyevna told her friend that "she did not understand anything", and turned her back to her, dropped her Russian language once and for all and continued speaking Vepsian to the other women. Veps often describe themselves as modest people and do not like to stand out in the crowd, neither for the better nor the worse. In fact, this appears to be a common behaviour also among Russian villagers as it secures a greater social cohesion (see also

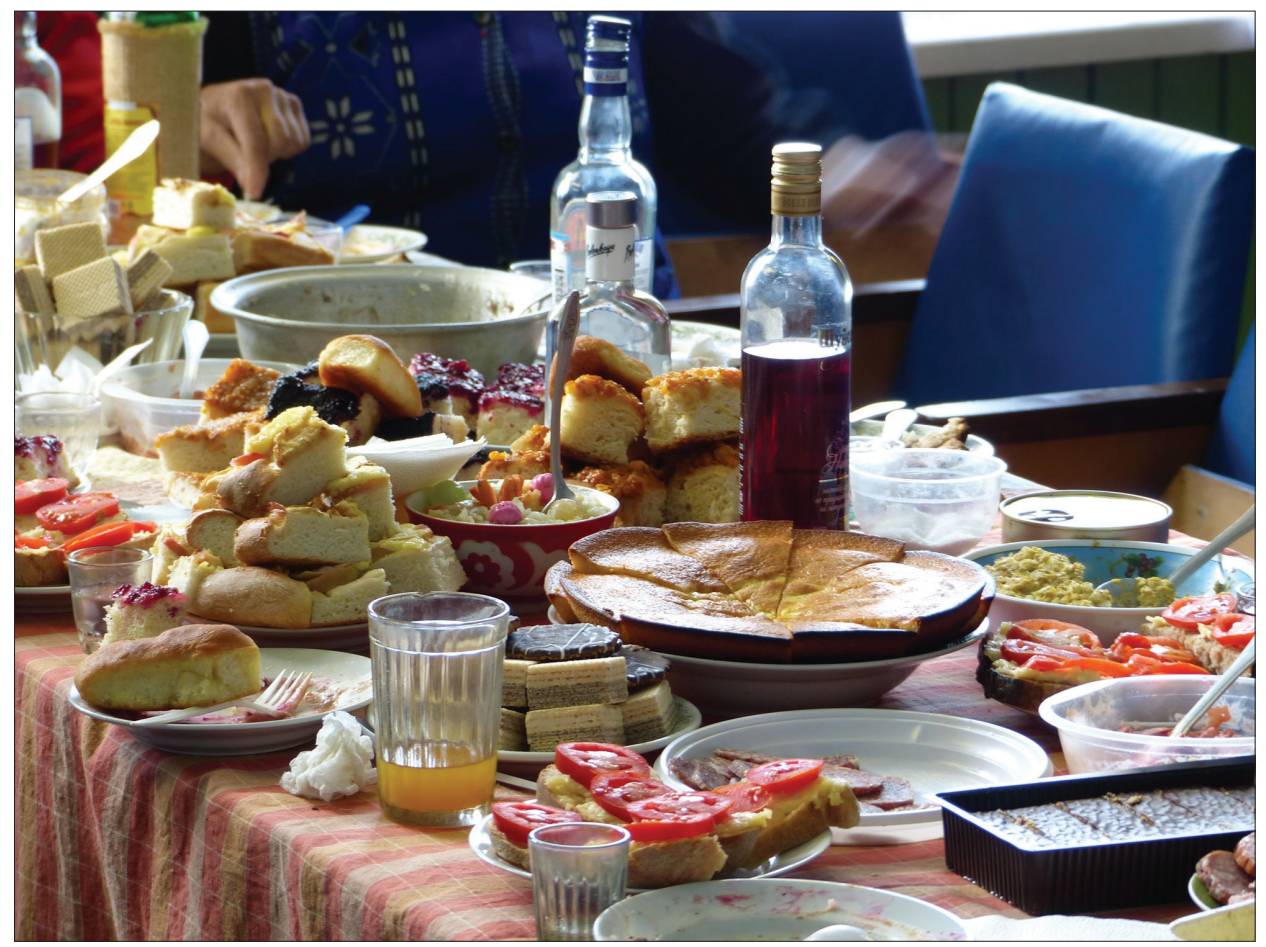

Figure 3. The Day of the Elderly in Pondala on October 1, 2013. All the villagers contributed to the event by bringing homemade cakes, sandwiches, salads, and drinks. Photograph by Laura Siragusa 2013. 
Olson \& Adonyeva 2012: 234; Paxson 2005: 72-73). By accepting the compliments from Anastasia Yuryevna, Maria Alekseyevna would have put herself in a vulnerable position amongst her co-villagers. Hence, she not only refused to be referred to as the "best villager", but she also refused to speak Russian, which the villagers generally perceived as an indicator of the world outside of the külä, and the world of political power, often dominated by Russians.

Anastasia Yuryevna had become embroiled in a hostile situation. This also emerged soon, through other bilingual language practices the villagers adopted. Indeed, the women who were sitting next to me began laughing rather openly at her, while speaking Vepsian among one another. They only spoke Russian to her when they decided to interfere with her private life which they did not consider exemplary. Ekaterina Ivanovna was sitting at the other end of the table and silently observed these verbal interactions. As a city dweller herself who had faced some integration difficulties in Narva, she could sympathise with Anastasia Yuryevna and her position as an outsider. Yet, complying with the other villagers, she suggested, "Nastia [Anastasia Yuryevna], you need to learn Vepsian. You have often visited the village, so it is time to learn the language! This will help you." Indeed, the women did not employ such discriminating language practices with me as I had already shown my interest in the Vepsian language and culture. And many of the villagers appreciated it and made reference to how they had often corrected me and taught me to speak Vepsian, i.e. their dialect, properly.

I should also indicate that the villagers in Pondala tend not to drink heavily during the week, or when no particular celebration is taking place, in contrast to the dwellers of other villages in Leningrad Oblast which I visited during my fieldwork. I could not find any evidence in the connection between presentday drinking patterns, historical events, and the geographical distribution of Vepsian settlements. Vinokurova (1996), who has deeply investigated Vepsian traditional practices, has shown that northern Veps consumed a very limited amount of alcohol in the past. Northern Veps were not accustomed to brewing and/or drinking beer. They mostly consumed kissel, milk and turnip kvas. ${ }^{8}$ Strong spirits were only consumed during festivities and Vinokurova (ibid.: 48) claims that, in fact, their presence was 'mostly symbolic'. During festivities, the favourite drinks were chay (Rus. 'tea') (possibly, as a symbol of wealth), often enjoyed with a pie made with milk and/or tvorog (Rus. 'cottage cheese') (ibid.: 47). Overall, women rarely drank, unless they attended a wedding (ibid.: 48). Girls would refuse to dance with someone who was clearly drunk. Central western Veps used to drink also turnip kvas like northern Veps, which they made when they baked turnip cakes (Mullonen \& Zaitseva 1969: 42). Milk and a third kind of kvas from tvorog were also among their customary drinks. Wine 
used to be too expensive and they did not buy it (ibid.). Mullonen and Zaitseva (ibid.: 219) reported that central western Veps used to have similar drinking habits as those in Leningrad Oblast. They also brewed beer right before joining some kind of festivity. Veps in Pondala demonstrated to have maintained such a drinking pattern; that is, to be drinking spirits and alcohol mostly during convivial events.

It is not uncommon that people use abusive language during convivial and drinking events. Specific practices and behaviours are socially acceptable during recreational times (Gusfield 1987). Bakhtin (1984: 10) demonstrated how convivial events, such as the Carnival, "celebrated temporary liberation from the prevailing truth and from the established order; it marked the suspension of all hierarchical rank, privileges, norms and prohibitions". Harvey (1991: 2) made similar considerations when observing language use in the Southern Peruvian Andes, and explained that generally "drunken speakers tend to be far less sensitive saving face than sober speakers, and their words are thus more likely to lead to insult or embarrassment". Price (1975) also stressed how drinking helps them to release their inhibition and express themselves more freely, and I would add that it helps bring to the surface social and political tensions, language attitudes, ideologies and practices, which would otherwise remain in the shadows.

The vignette in Pondala reveals linguistic strategies adopted by bilingual speakers of Vepsian and Russian in a rather isolated Vepsian village, and their social symbolism. These strategies reflect language and social ideologies among Vepsian villagers which, otherwise, people disclose more subtly (if at all). For example, close Vepsian friends had often remarked on how they did not favour displays of grandeur which they considered to be spread "among Russians". They disclosed that Veps were more modest and not "as loud" both in their ways of speaking and in their general ways of presenting themselves socially. They also regarded Vepsian women as less boisterous in their way of dressing and this was considered proper female behaviour. Yet, these observations were often done behind 'closed doors', on a personal level, secretly. Otherwise, Veps demonstrated to quietly accept and 'tolerate' (as some stressed) behavioural differences among the multi-ethnic territory in which they lived. These conceptual differences find expression in the oral use of the language in Vepsian rural territory, matching both traditional Vepsian epistemologies and long-established political tensions. Engaging in bilingual and/or monolingual practices can open or close channels of communication and experiences of unity with other human and non-human beings, and the environment, once the status quo is shaken. Hidden tensions and attitudes towards power (in this case symbolised by a Russian woman) came to the surface during the festivity in Pondala. The attendees revealed 
language attitudes and verbal demonstrations of dissent against prevailing social norms which Veps rarely manifest in everyday life. This vignette exhibits a complex scenario in which tensions and power in the heritage language and the woods converge. The Vepsian villagers demonstrated how verbal practices in the heritage language and Russian are closely convoluted in exclusion and inclusion techniques and in reversing power relations.

The ideal social agreement that Veps look for when engaging with the spirits, human and non-human animals in the woods, and when engaging with non-Vepsian speakers, was openly dropped as soon as alcohol was consumed abundantly and they could support one another. The villagers demonstrated agency when they empowered themselves with the ability to manage relational channels through bilingual and monolingual speech acts. They not only allowed openness and unity with the world but also closure. Similarly, Billé et al. (2012) adopted the metaphor of a "slightly complicated door" when referring to geopolitical frontiers. Indeed, employing specific language strategies means that somebody is being discriminated against, or put aside, voluntarily or not, from certain social activities and experiences.

\section{CONCLUSION}

Despite the desired social agreement, tensions and uneven power relations can suddenly become apparent via mono- and bilingual verbal practices. Among Veps, avoiding verbal conflict often guarantees safety. When engaging with humans and non-humans in traditional rural settlements, this often implies refraining from swearing, using positive language, being respectful and thankful for what is given by the land. When engaging with non-Vepsian speakers in north-western Russia, this might also imply embracing a monolingual (Russian) way of speaking. Dropping such soothing and reassuring oral practices may harm the population; thus, Veps prefer to either engage in conflictual verbal practices secretly or avoid them entirely. This continuous negotiation with the overarching language ecology, comprising rural and urban settings and prevailing metaphors and ideologies, reveals agency and power in verbal practices. This paper has shown how the thin balance upon which political and social tensions reside might break during convivial settings in a remote village of the Vologda Oblast.

The convivial event that took place in Pondala in October 2013 demonstrated a break from the ordinary status quo. The consumption of alcohol enabled Veps to restore a balance of power between different agencies. And manifesting power through the use of their heritage language called into question habitual lan- 
guage interaction and dynamics which instead reinforce differences of political and social power. Therefore, social drinking can be read as a strategy to reestablish (or reverse) power relations thanks to its potential for liberating one from certain social rules. Such liberation also extends to oral language use. Yet, the village dwellers in Pondala seemed to accept this temporary suspension of ordinary life, as long as it was only temporary. This particularly referred to the use of alcohol. A few days after the convivial event at the House of Culture, the villagers shut themselves indoors in the evenings. This was a habit which they usually did not practice. Yet, a neighbour kept wandering around the village asking for booze, and they passed the message on to one another and decided to close their doors in the evening. In Pondala drinking in abundance initially opened the channels of communication, thereafter interrupting them on the verbal level, until it finally shut down any possible interaction.

\section{ACKNOWLEDGEMENTS}

This work was supported by the Estonian Research Mobility Scheme grant (ERMOS120), the ERC Advanced Grant (Arctic Domus project No. 295458), by the Estonian Ministry of Education and Research (IUT34-32), and by the Finnish Academy (HuSArctic).

\section{NOTES}

1 I have decided to use pseudonyms in this article since I am later presenting a conflictual event and do not intend to expose any of the persons involved in the episode. For a matter of consistency, I use pseudonyms also where no conflict occurred. However, this decision does not comprise those who hold a public position, such as Nadezhda Pavlovna.

${ }^{2}$ I translated this sentence and other excerpts in the article from Russian into English. I will indicate when otherwise.

${ }^{3}$ My fieldwork with Veps extends to a few years. I began conducting research among Veps in 2009 and spent a whole year in this north-western territory of Russia. I returned for two months in the summer of 2011 to check my work together with Veps and continue my research. After completing my doctoral studies in 2012, I returned several times to Vepsian villages throughout 2013. In 2014, I mainly visited urban centres, as I was working in the archives of Petrozavodsk and St. Petersburg.

4 See Gramsci (1975) on how to obtain hegemony in society through a subtle process of force. 
5 The forest, the lakes, the swamps, and the rivers are included in the Vepsian word külä (Veps 'village') (Mullonen 2005), which differs from the words derüun (central Vepsian dialect) and posad (northern Vepsian dialect), only indicating the village where there is a pagast (Veps 'churchyard').

${ }^{6}$ I also found this information in the phonogram archives of the Institute of Linguistics, History and Literature at the Academy of Sciences in Petrozavodsk, in the Republic of Karelia (ANKTs).

7 Chastushka is an originally Russian rhyming folk poem that Veps also employ in Vepsian.

${ }^{8}$ Kissel is a jelly-looking dessert, made form sweetened juice or milk and thickened with arrowroot or potato starch. Kvas is a fizzy drink made from fermented rye bread.

\section{MANUSCRIPT SOURCES}

Fieldwork notes from 2010 and 2013 in possession of the author.

\section{ARCHIVAL SOURCES}

AKNTs = Arkhiv Karel'skogo nauchnogo tsentra [Archive of the Karelian Scientific Centre]

\section{REFERENCES}

Ahearn, Laura M. 2001. Language and Agency. Annual Review of Anthropology, Vol. 30, pp. 109-137. http://dx.doi.org/10.1146/annurev.anthro.30.1.109.

Anderson, David G. 1991. Turning Hunters into Herders: A Critical Examination of Soviet Development Policy among the Evenki of Southeastern Siberia. Arctic, Vol. 44, No. 1, pp. 12-22. http://dx.doi.org/10.14430/arctic1513.

Bakhtin, Mikhail 1984. Rabelais and His World. Bloomington: Indiana University Press. Available at http://monoskop.org/images/7/70/Bakhtin_Mikhail_Rabelais_and_ His_World_1984.pdf, last accessed on April 29, 2015.

Bateson, Gregory 1972. Steps to an Ecology of Mind: Collected Essays in Anthropology, Psychiatry, Evolution and Epistemology. Aylesbury: Intertext.

Billé, Franck \& Delaplace, Grégory \& Humphrey, Caroline 2012. Frontier Encounters: Knowledge and Practice at the Russian, Chinese and Mongolian Border. Cambridge: Open Book Publishers.

Blommaert, Jan 2010. The Sociolinguistics of Globalization. Cambridge: Cambridge University Press.

Conquest, Robert 1986. The Harvest of Sorrow: Soviet Collectivization and the TerrorFamine. London \& Melbourne: Hutchinson. 
Cruikshank, Julie 2005. Do Glaciers Listen? Local Knowledge, Colonial Encounters, and Social Imagination. Vancouver: University of British Columbia Press.

Garner, Mark 2004. Language: An Ecological View. Oxford: Peter Lang.

Gelb, Michael 1993. 'Karelian Fever': The Finnish Immigrant Community during Stalin's Purges. Europe-Asia Studies, Vol. 45, No. 6, pp. 1091-1116. http://dx.doi. org/10.1080/09668139308412142.

Gramsci, Antonio 1975. Quaderni del carcere. Torino: Giulio Einaudi.

Grandstaff, Peter J. 1980. Interregional Migration in the U.S.S.R.: Economic Aspects, 1959-1970. Durham, North Carolina: Duke University Press.

Grünthal, Riho 2011. Population Decline and the Erosion of the Veps Language Community. In: R. Grünthal \& M. Kovác (eds.) Ethnic and Linguistic Context of Identity: Finno-Ugric Minorities. Uralica Helsingiensia 5. Helsinki: SuomalaisUgrilainen Seura, pp. 267-293. Available at http://www.sgr.fi/uh/uh5.pdf, last accessed on April 29, 2015.

Gusfield, Joseph 1987. Passage to Play: Rituals of Drinking Time in American Society. In: Mary Douglas (ed.) Constructive Drinking: Perspectives on Drink from Anthropology. Cambridge: Cambridge University Press, pp. 73-90.

Guss, David 1986. Keeping It Oral: A Yekuana Ethnology. American Ethnologist, Vol. 13, No. 3, pp. 413-429. http://dx.doi.org/10.1525/ae.1986.13.3.02a00010.

Hanks, William 1996. Language and Communicative Practices. Boulder \& Oxford: Westview Press.

Harvey, Penny 1991. Drunken Speech and the Construction of Meaning: Bilingual Competence in the Southern Peruvian Andes. Language in Society, Vol. 20, No. 1, pp. 1-36. http://dx.doi.org/10.1017/S0047404500016055.

Ingold, Tim 2004. Culture on the Ground: The World Perceived through the Feet. Journal of Material Culture, Vol. 9, No. 3, pp. 315-340. http://dx.doi. org/10.1177/1359183504046896.

Kaiser, Robert J. 1994. The Geography of Nationalism in Russia and the USSR. Princeton, New Jersey: Princeton University Press.

Kettunen, Lauri \& Siro, Paavo 1935. Näytteitä Vepsän Murteista. [Samples of Vepsian Dialects.] Helsinki: Suomalais-Ugrilainen Seura.

King, Alexander D. 2011. Living with Koryak Traditions: Playing with Culture in Siberia. Lincoln \& London: University of Nebraska Press.

Kirshenblatt-Gimblett, Barbara 1998. Destination Culture: Tourism, Museums, and Heritage. Berkeley \& Los Angeles \& London: University of California Press.

Klementyev et al. 2007 = Klement'ev, Evgenii \& Kozhanov, Aleksandr \& Strogal'shchikova, Zinaida. Vepsy: modeli etnicheskoi mobilizatsii. Sbornik materialov i dokumentov. [Veps: Models of Ethnic Mobilisation.] Petrozavodsk: Karel'skii nauchnyi tsentr RAN.

Kolesov, Aleksandr et al. (eds.) 2007. Karelia: Guidebook. Petrozavodsk: Scandinavia. Kostiainen, Auvo 1996. Genocide in Soviet Karelia: Stalin's Terror and the Finns of Soviet Karelia. Scandinavian Journal of History, Vol. 21, No. 4, pp. 331-342. http://dx.doi.org/10.1080/03468759608579334.

Kurs, Ott 2001. The Vepsians: An Administratively Divided Nationality. Nationalities Papers, Vol. 29, No. 1, pp. 69-83. http://dx.doi.org/10.1080/00905990120036385. 
Laine, Antti 2001. Where East Meets West: The Last Stand of Finns and Karelians in Contemporary Karelia? Nationalities Papers, Vol. 29, No. 1, pp. 53-67. http:// dx.doi.org/10.1080/00905990120036420.

Leasure, William James \& Lewis, Robert 1967. Internal Migration in the USSR: 1897 1926. Demography, Vol. 4, No. 2, pp. 479-496. http://dx.doi.org/10.2307/2060294.

Mead, William R. 1952. Finnish Karelia: An International Borderland. The Geographical Journal, Vol. 118, No. 1, pp. 40-54. http://dx.doi.org/10.2307/1791235.

Mühlhäusler, Peter 1996. Linguistic Ecology: Language Change and Linguistic Imperialism in the Pacific Region. London \& New York: Routledge.

Mühlhäusler, Peter 2000. Language Planning and Language Ecology. Current Issues in Language Planning, Vol. 1, No. 3, pp. 306-367. http://dx.doi. org/10.1080/14664200008668011.

Mullonen, Irma 2005. Vepsian Oikonymy. Onomastica Uralica 3: Settlement Names in the Uralian Languages, pp. 51-64.

Mullonen, Irma 2012. Prirodnye i kul'turnye faktory formirovaniia vepsskoi etnicheskoi territorii. [Natural and Cultural Factors in the Formation of Vepsian Ethnic Territory.] Trudy Karel'skogo nauchnogo tsentra RAN 4, pp. 13-24. Available at http://transactions.krc.karelia.ru/publ.php?plang=r\&id=10107, last accessed on April 30, 2015.

Mullonen \& Zaitseva 1969 = Mullonen, Mariia \& Zaitseva, Mariia. Obraztsy vepsskoi rechi. [Vepsian Speech Samples.] Leningrad: Nauka.

Olson, Laura J. \& Adonyeva, Svetlana 2012. The Worlds of Russian Village Women: Tradition, Transgression, Compromise. Madison, Wisconsin: The University of Wisconsin Press.

Paxson, Margaret 2005. Solovyovo: The Story of Memory in a Russian Village. Washington, D.C.: Woodrow Wilson Center Press; Bloomington, Indiana: Indiana University Press.

Philips, Susan U. 1999. Power. Journal of Linguistic Anthropology, Vol. 9, Nos. 1-2, pp. 194-196. http://dx.doi.org/10.1525/jlin.1999.9.1-2.194.

Price, John A. 1975. An Applied Analysis of North American Indian Drinking Patterns. Human Organization, Vol. 34, No. 1, pp. 17-26.

Puura, Ulriikka \& Karjalainen, Heini \& Zaitseva, Nina \& Grünthal, Riho 2013. The Veps Language in Russia: ELDIA Case-Specific Report. Studies in European Language Diversity 25. Mainz \& Wien \& Helsinki \& Tartu \& Mariehamn \& Oulu \& Maribor. Available at https://fedora.phaidra.univie.ac.at/fedora/get/o:315545/ bdef:Content/get, last accessed on April 30, 2015.

Salminen, Timo 2009. In Between Research, the Ideology of Ethnic Affinity and Foreign Policy: The Finno-Ugrian Society and Russia from the 1880s to the 1940s. In: Jussi Ylikoski (ed.) The Quasquicentennial of the Finno-Ugrian Society. SuomalaisUgrilaisen Seuran Toimituksia = Mémoires de la Société Finno-Ougrienne 258. Helsinki: Société Finno-Ougrienne, pp. 225-262. Available at http://www.sgr.fi/ sust/sust258/sust258.pdf, last accessed on April 30, 2015.

Schieffelin, Bambi B. \& Woolard, Kathrin A. \& Kroskrity, Paul 1998. Language Ideologies: Practice and Theory. New York \& Oxford: Oxford University Press. 
Setälä, Eemil \& Kala, Juho \& Tunkelo, Eemil \& Peltola, Reino 1951. Näytteitä Ä̈̈nis- ja Keski-Vepsän murteista. [Samples of the Onega and Central Vepsian Dialects.] Helsinki: Suomalais-Ugrilainen Seura.

Shearer, David R. 2006. Stalinism, 1928-1940. In: Ronald G. Suny (ed.) The Cambridge History of Russia. Volume 3: The Twentieth Century. Cambridge: Cambridge University Press, pp. 192-216. http://dx.doi.org/10.1017/CHOL9780521811446.009.

Slezkine, Yuri 1994. Arctic Mirrors: Russia and the Small Peoples of the North. Ithaca \& London: Cornell University Press.

Smith, Jeremy 1999. The Bolsheviks and the National Question, 1917-23. London: MacMillan Press Limited.

Smith, Laurajane \& Akagawa, Natsuko (eds.) 2009. Intangible Heritage. London \& New York: Routledge.

Strogalshchikova 2004 = Strogal'shchikova, Zinaida. Problemy stanovleniia natsional'nogo obrazovaniia karelov i vepsov na sovremennom etape. [Problems of the Formation of Karelians' and Veps' National Education at Present.] In: Sovremennoe sostoianie $i$ perspektivy razvitiia karel'skogo, vepsskogo i finskogo iazykov $v$ Respublike Kareliia. Materialy nauchno-prakticheskoi konferentsii 31 oktiabria 2002 goda. Petrozavodsk, pp. 41-47.

Strogalshchikova 2008 = Strogal'shchikova, Zinaida (ed.) Vepsy: na rubezhe $X X-X X I$ vekov. Po materialam mezhregional'noi nauchno-prakticheskoi konferentsii 'Vepsy korennoi malochislennyi narod Rossiiskoi Federatsii: perspektivy sokhraneniia $i$ razvitiia'. [Veps: At the Turn of the Century. Materials from Inter-regional Scientific and Practical Conference 'Veps - Indigenous Minority of the Russian Federation: Perspectives for Maintenance and Development'.] Petrozavodsk: Karel'skii nauchnyi tsentr RAN.

Vinokurova, Irina 1996. Traditsionnye prazdniki vepsov Prionezh'ia (konets XIX-nachalo $X X$ v.). [Vepsian Traditional Festivities in the Prionezh'iye (end of the 19th beginning of the 20th cc.).] Petrozavodsk: Izdatel'stvo PetrGU.

Vinokurova, Irina 2006. Zhivotnye $v$ traditsionnom mirovozrenii Vepsov. [Animals in Veps' Traditional Worldview.] Petrozavodsk: Izdatel'stvo PetrGU.

Woolard, Kathrin A. \& Schieffelin, Bambi B. 1994. Language Ideology. Annual Review of Anthropology, Vol. 23, pp. 55-82. http://dx.doi.org/10.1146/annurev. an.23.100194.000415.

Yegorov 2006 = Egorov, Sergei. Vepssko-Russkoe mezhetnicheskoe vzaimodeistvie. [Vepso-Russian Interethnic Interactions.] In: N. Bogdanov \& I. Vinokurova (eds.) Sovremennaia nauka o Vepsakh: dostizheniia i perspektivy (pamiati N. I. Bogdanova). Petrozavodsk: Karel'skii nauchnyi tsentr RAN, pp. 237-248.

Zaiceva, Nina 1995. Vepsän kelen grammatik. [Grammar of the Vepsian Language.] Petroskoi: Petroskoin valtionyliopiston kustantamo. 